\title{
酸素ラジカルビーム照射による超伝導薄膜成長に 及ぼす効果*
}

小室 修二**・パトリック・オキーフ**.田 昭治****

森川 滝太郎***. 青柳 克信 $* *$

（受付1990年12月 3 日，掲載決定1991年 2 月 2 日）

Superconding Thin Film Preparation in the Presence of an Oxygen Radical Beam

\author{
Shuji KOMURO**, Patrick O'KEEFFE**, Shoji DEN, ${ }^{* * * *}$ \\ Takitaro MORIKAWA ${ }^{* * *}$ and Yoshinobu AOYAGI** \\ ** (The Institite of Physical and Chemical Research, Wako, Saitama) \\ *** (Toyo University, Kawagoe Saitama) \\ **** (Irie Koken Co., Ltd., Kawagoe, Saitama)
}

(Received December 3, 1990, Accepted February 2, 1991)

\section{1. はじめに}

近年，電子サイクロトロン共鳴（ECR）を利用した プラズマ発生装置が数多く製作されている. ECR プラ ズマは無電極放電で発生できることから，寿命が長いこ と，低ガス圧で放電が持続できること，プラズマ密度が 高いなど多くの利点を持っている. 従って, 反応性の強 いガス(酸素，塩素など)のプラズマ発生に有利である. 我々は ECRキャビティーが小型で, UHVチャンバー 中に挿入できるラジカルビームガンを開発し，その応用 の一例として酸化物超伝導薄膜の作成を試みた。その結 果, 酸素ラジカルが高品質の酸化物薄膜作成に有効であ ることが明らかになったので報告する。

\section{2. 小型ラジカルビームガンの開発}

今回開発した酸素ラジカルガンの構造を Fig. 1 に示 す. 周波数 $2.45 \mathrm{GHz}$, 最大供給電力 $300 \mathrm{~W}$ のマイクロ 波は，同軸ケーブルによりコネクタ端子から供給され

* 1990年10月25日 第31回真空に関する連合講演会で講演 $(25 \mathrm{Bp}-2)$

** 理化学研究所 (和光市広沢2-1)

*** 東洋大学工学部（川越市鯨井中野台2100）

**** 入江工研 (川越市下赤坂大野原740-5)
る．また，反射波からマグネトロンを保護するために単 向管，入射電力执よび反射電力をモニタ一するためのパ ワーメータ，負荷と同調をとるためのスタブチューナが 取り付けられている。外部から供給されたマイクロ波 は，アンテナを通り放電キャビティーに送られる。キャ ビティーは直径 $10 \mathrm{~mm}$, 長さ $25 \mathrm{~mm}$ と小型である. ECR 放電を起こすために, 875 Gauss のリン゙グ状のマグ ネットがキャビティーに内臓されている．放電による発 熱を防ぐために，キャビティ一は水冷される。キャビテ ィーに送られた酸素ガスは, ECR 放電によりプラズマ

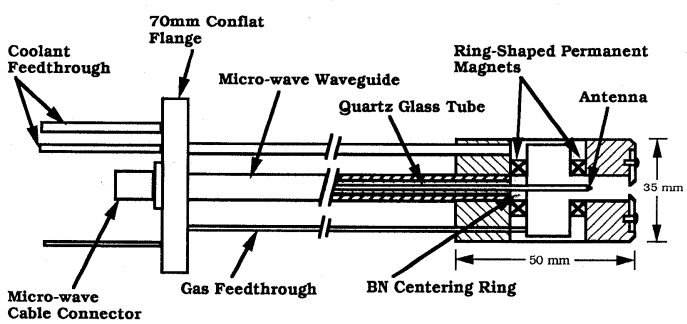

Fig. 1 Cross section of compact radical gun 


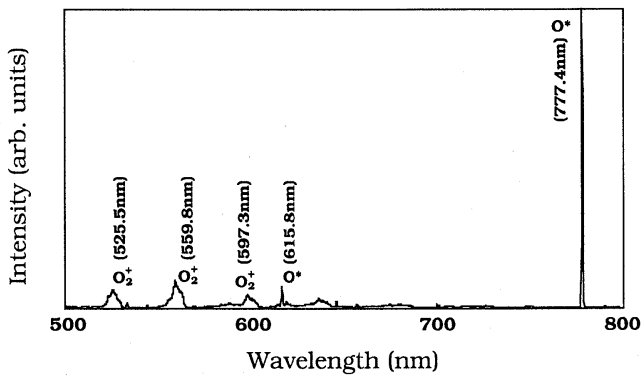

Fig. 2 Optical emission spectra of the ECR oxygen plasma

化され，その酸素プラズマは真空チャンバーとキャビテ ィ一内の圧力差により. 直径 $6 \mathrm{~mm}$ のオリフィスを通し 真空チャンバー内にビーム状に放出される. 入力電力 $100 \mathrm{~W}$ では酸素プラズマを $10^{-5} \sim 0.1$ Torr のチャンバー 圧力において安定に発生することができる.

酸素プラズマ中に含まれる活性種は, 発光分光測定法 により測定された，波長 $500 \mathrm{~nm} \sim 800 \mathrm{~nm}$ において観測 された酸素プラズマの発光分析結果を Fig. 2 に示す. 測定条件は酸素圧力 $1 \times 10^{-3}$ Torr，キャビティーへの酸 素ガス流量1.7 sccm である. Fig. 2 のスペクトルから分 かるように, 酸素の活性種はプラズマ中には酸素分子イ オン（ $\mathrm{O}_{2}^{+}$; 波長525.6, 559.8, $597.3 \mathrm{~nm}$ など） と酸素ラ ジカル $\left(\mathrm{O}^{*} ; 615.8,645.6,777.4 \mathrm{~nm}\right.$ など）として存在 していることが分かる. 負荷との同調が不完全な場合, O*の発光強度は急激に減少する. Fig. 3 に O*（波長 $777.4 \mathrm{~nm})$ と $\mathrm{O}_{2}^{+}(559.8 \mathrm{~nm})$ の発光ピーク強度の酸素 圧力依存性を示す. $\mathrm{O}^{*}$ と $\mathrm{O}_{2}^{+}$の発光ピーク強度は圧力 の増加と共にわずかに減少する。これら活性種の定量測 定は発光分光測定結果から見積ることは困難であるが， 少なくとも $10^{-4} \sim 0.1$ Torr の圧力範囲では酸素ラジカル と酸素分子イオンの活性種の存在は確認される. Fig. 4 にラングミュア探針法により測定した電子密度 $\mathrm{Ne}$ と電 子温度 $\mathrm{Te}$ の酸素圧力依存性を示す．プラズマパラメー タの測定は, ラジカルガンのヘッド部より $25 \mathrm{~mm}$ 離れ た位置で行った。酸素圧力 $10^{-4} \sim 10^{-2}$ Torr では図に示 すよらに $\mathrm{Ne}$ は酸素圧力と共に増加するが， Teは逆に 減少する. $10^{-2}$ Torr では, $\mathrm{Ne}=10^{10} \mathrm{~cm}^{-3}, \mathrm{Te}=5 \mathrm{eV}$ で あり，典型的な ECRによる酸素プラズマが生成されて いる.

\section{3. 酸素ラジカルガンの応用‥酸化物超伝導 薄膜の作成}

前述した酸素ラジカルガンを用いた応用例として，酸 化物超伝導薄膜作成を行った。レーザーアブレーション

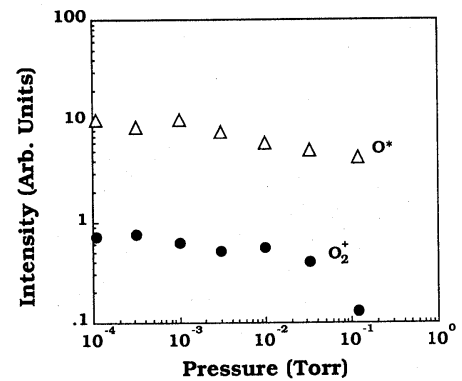

Fig. 3 Emission intensity dependence on oxygen pressure of oxygen radical $\left(\mathrm{O}^{*}\right)$ and oxygen ion $\left(\mathrm{O}_{2}^{+}\right)$

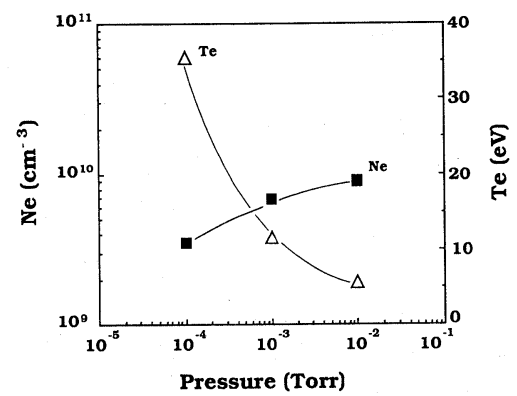

Fig. 4 Oxygen pressure dependence of electron density $(\mathrm{Ne})$ and electron temperature $(\mathrm{Te})$

法による薄膜作成装置の概略図を Fig. 5 に示す，真空 チャンバーの到達真空度は, $8 \times 10^{-10}$ Torr である。レ ーザーは KrF（波長 $248 \mathrm{~nm}, 1$ パルスあたりの強度約 1 $\left.\mathrm{J} / \mathrm{cm}^{2}\right)$ エキシマレーザー, ターゲットは化学量論組成 比の $\mathrm{YBa}_{2} \mathrm{Cu}_{3} \mathrm{Ox}$ を，また基板は $\mathrm{MgO}(100)$ を用いた。 ターゲットと基板は対向して配置され，その間隔は約 5 $\mathrm{cm}$ である. 成膜条件は酸素ガス圧力 $1.2 \times 10^{-2}$ Torr, 酸素ガス流量 $1.1 \mathrm{sccm}$, 基板温度 $\mathrm{Ts}=640^{\circ} \mathrm{C}$ である。 $\mathrm{Ts}$ は成膜中一定とし, 成膜後室温まで $4^{\circ} \mathrm{C} / \mathrm{min}$ の冷却率 で徐冷し，ポストアニールは行わなかった，成膜された 超伝導薄膜の抵抗率の温度依存性を四端子法により測定 した。 ここで，超伝導薄膜作成時における酸素分子イオ ンと酸素ラジカルの効果を知るために，成膜中および冷 却中に亘ってレーザープルーム中および基板に照射する 酸素プラズマの照射方向に垂直に磁場を印加して成膜を 行った．酸素プラズマ中に含まれる荷電粒子は進行方向 および磁場方向に垂直なローレンツカを受けることによ って進行方向が曲げられ，照射プラズマ中から除かれる ことになる。したがって，簡易的にレーザープルームお よび基板に照射されるプラズマ中のラジカル・イオンの 含有比 $\left(\mathrm{O}^{*} / \mathrm{O}_{2}^{+}\right)$は印加磁場により制御される. 発光 


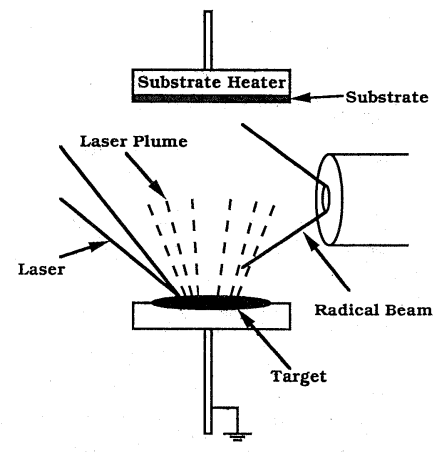

Fig. 5 Schematic diagram of laser ablation method for superconducting thin film preparation using oxygen radical gun

分光測定の結果では, 印加磁場が OGauss から50 Gauss まで変化させると, Fig. 3 亿示した $\mathrm{O}^{*}$ と $\mathrm{O}_{2}^{+}$の発光強 度比は約 2 倍増加することから, 印加磁場によりプラズ マは相対的にラジカルリッチ状態になると考光られる. また，比較のために ECR 放電を行わず，酸素がスをそ のま照射して得られた薄膜の特性も測定した。これら の結果をまとめて Fig. 6 に示す．ECR 放電を行わない 場合（Fig. 6 中 “ $\mathrm{O}_{2}$ ” で示す）では，抵抗率は半導体的 であり超伝導特性を示さない。しかし，ECR 放電によ り生成した酸素プラズマを照射する（Fig. 6 中 “ECR”で示す）と，抵抗率は金属的特性を示すととも に超伝導特性も現れる。これは明かにプラズマ中の酸素 活性種が, 酸化物超伝導薄膜作成に効果的な酸化反応を 促進することに起因すると思われる1)。また，前述した 方法で磁場を印加することによってラジカルガンからの プラズマをラジカルリッチ状態で照射した方が超伝導遷 移温度 $\mathrm{Tc}=57 \mathrm{~K}$ から $70 \mathrm{~K}$ と $13 \mathrm{~K}$ だけ $\mathrm{Tc}$ が上昇するこ とが観測された。この結果は, 酸素ラジカルの方が酸素 分子イオンよりも膜中に取り込まれ易く，また表面での 吸着係数が大きくょり活性であると考えられる.さらに 膜表面一の活性粒子の衝撃による照射損傷を考光た場 合，ラジカル照射はイオンに較べはるかに軽減できる． 以上の結果をまとめると, 酸化物薄膜作成には酸化反応 を促進するため酸素活性種が必要であるが，その中でも 酸素イオンよりも，酸素ラジカルがより効果的であると

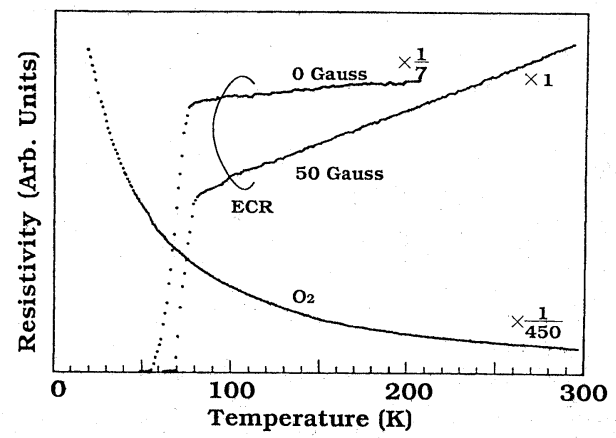

Fig. 6 Temperature dependence of resistivity of superconducting thin films prepared at $\mathrm{Ts}=640^{\circ} \mathrm{C}$

考光られる

\section{4. まとめ}

ECR 放電型で小型のプラズマ源として酸素ラジカル ガンを開発した。このプラズマ特性は酸素圧力 $10^{-2}$ Torr で電子温度 $\mathrm{Te}=5 \mathrm{eV}$, 電子密度 $\mathrm{Ne}=1 \times 10^{10} \mathrm{~cm}^{-3}$ であり, プラズマ発光分光測定からプラズマ中には，酸 素分子イオン, 酸素ラジカルの活性種が含まれているこ とを確認した，この酸素ラジカルガンをY系酸化物超 伝導薄膜の作成に適用した結果，ECR 放電なしの酸素 ガス照射では超伝導特性は発現しないが，ECR 放電に よる酸素プラズマを照射した場合には超伝導特性が発現 することから，プラズマ中の酸素活性種が酸化物超伝導 薄膜を作成するのに必要であることを明らかにした。さ らに, 酸素活性種の内, 酸素イオンよりも酸素ラジカル の方が超伝導遷移温度に上昇が見られることから，酸素 ラジカルは酸化物超伝導薄膜作成に効果的であるを明ら かにした。

\section{〔文献〕}

1）パトリック・オキーフ，パトリック・キーティン グ, 田 昭治, 小室修二, 森川滝太郎, 青柳克信, 酸 素ラジカルビーム照射の超伝導薄膜作成及ぼす効果, 第51回応用物理学会学術講演会予稿集第 1 分冊, $\mathrm{p}$ 107, 1990. 